\title{
Urgensi Teknologi Pendidikan Dalam Peningkatan Kualitas Pembelajaran Daring
}

\author{
Galantri Isra' Fania ${ }^{1 *}$, Ria Nur Khasanah ${ }^{2}$, Unik Hanifah Salsabila ${ }^{3}$, Rahma \\ Haifani Azizah ${ }^{4}$, Anisa Listiyani ${ }^{5}$ \\ 1,2,3,4,5 Universitas Ahmad Dahlan, Indonesia \\ email: galantri1911331016@webmail.uad.ac.id
}

\begin{abstract}
During the COVID-19 pandemic, it has changed many sectors of human life, including the education sector. Many schools are reducing activities at school or even completely closing schools, only doing distance learning. Therefore, with distance learning, adequate technology and competent human resources are needed. This study aims to find out what educational technology is, how technology plays a role in education, what are the obstacles in the application of educational technology and how to use technology in schools, especially during the covid-19 pandemic. In this study the author uses qualitative methods (library studies and interviews), in collecting data the authors look for several sources of reading that are in accordance with the topic of discussion, be it from the internet, online journals or books. Then the author conducted an interview with one of the teachers at SDN Bojong through a virtual forum. From the results of the interview, it can be seen that the use of technology at SDN Bojong has not been effective, there are still many obstacles or obstacles in its implementation. However, educators continue to strive for the best in the use of technology so that they can help students in the learning process, so that students feel comfortable.
\end{abstract}

\section{Keywords: Urgency, Role, Technology, Education}

\begin{abstract}
Abstrak: Pada masa pandemi covid-19 telah merubah banyak sektor kehidupan manusia, termasuk sektor pendidikan. Banyak sekolah yang mengurangi kegiatan di sekolah atau bahkan sepenuhnya menutup sekolah, hanya melakukan pembelajaran jarak jauh. Oleh karena itu, dengan adanya pembelajaran jarak jauh maka dibutuhkan teknologi yang memadai serta sumber daya manusia yang memiliki kompetensi. Penelitian ini bertujuan untuk mengetahui apa itu teknologi pendidikan, bagaimana teknologi berperan dalam pendidikan, apa saja kendala dalam penerapan teknologi pendidikan serta bagaimana pemanfaatan teknologi di sekolah terutama pada mas pandemi covid-19. Dalam penelitian ini penulis menggunakan metode kualitatif (studi pustaka dan wawancara), dalam pengumpulan data penulis mencari beberapa sumber bacaan yang sesuai dengan topik bahasan, baik itu dari internet, jurnal online maupun buku. Kemudian penulis melakukan wawancara kepada salah satu guru di SDN Bojong melalui forum virtual. Dari hasil wawancara tersebut dapat diketahui bahwa pemanfaatan teknologi di SDN Bojong belum efektif, masih banyak kendala atau hambatan dalam pelaksanaanya. Namun para pendidik tetap mengupayakan yang terbaik dalam pemanfaatan teknologi agar dapat membantu siswa dalam proses pembelajaran, sehingga siswa merasa nyaman.
\end{abstract}

Kata kunci: peran teknologi pendidikan, pembelajaran, daring 


\section{PENDAHULUAN}

Pandemi covid-19 membawa banyak sekali perubahan terutama pada sektor pendidikan, yang mana dunia pendidikan mengalami perubahan secara signifikan. Peran teknologi sangat dibutuhkan pada era seperti sekarang ini. Lembaga pendidikan, institut, pemerintah maupun individu melakukan berbagai upaya guna memaksimalkan penggunaan teknologi (Ali dan Erihadiana, 2021). Dalam dunia pendidikan teknologi menjadi nilai tambah sekaligus memegang peranan yang sangat penting demi kelangsungan kegiatan pembelajaran. Teknologi merupakan buah dari ilmu pengetahuan dalam proses pendidikan maka sudah seharusnya pendidikan saat ini memanfaatkan teknologi yang ada bahkan terus menginovasi agar selalu mengikuti perkembangan zaman (Lestari, 2018). Pemanfaatan teknologi dalam pendidikan dapat memberikan jangkauan yang lebih luas terhadap ilmu pengetahuan, mengakses informasi serta dirasa lebih efektif dan efisien jika dimanfaatkan secara maksimal. Pengaruh dari perkembangan teknologi pada dunia pendidikan sangat terasa, sehingga peserta didik maupun pendidik dituntut untuk memahami teknologi yang ada. Teknologi menjadi sebuah kebutuhan yang dapat dirasakan oleh masyarakat baik daerah maupun perkotaan dalam upaya memajukan mutu pendidikan nasional. Proses pembelajaran dapat diartikan sebagai hubungan timbal balik yang dilakukan antara peserta didik dengan pendidik dalam melakukan transfer ilmu melalui media tertentu sehingga maksud yang ingin disampaikan tersampaikan secara jelas kepada peserta didik (Merliana, 2019). Adapun pembelajaran dapat diartikan sebagai proses komunikasi yang bertujuan menyampaikna informasi agar dapat diterima melalui perasaan, pikiran, maupun perhatian para peserta didik.

Dengan begitu maka dalam dunia pendidikan perlu adanya inovasi yang dilakukan untuk meningkatkan kualitas pendidikan. Dengan adanya inovasi, sebagai pendidik dapat menganalisis cara yang praktis dan efetif untuk menyampaikan informasi kepada peserta didik. Pemanfaatan teknologi dalam pembelajaran memberikan dampak yang positif, namun pada kenyataanya banyak sekolah-sekolah belum bisa memaksimalkan kemajuan teknologi yang terjadi. Permasalahan dalam dunia pendidikan biasanya disebabkan oleh masalah kualitas pendidikan yang mempengaruhi kualitas pembelajaran. Pemerataan pembangunan 
dalam bidang pendidikan pun dirasa masih kurang sehingga kondisi pandemi covid seperti sekarang, sebagian kecil sekolah-sekolah yang terkendala dalam memanfaatkan teknologi pendidikan akibat kurangnya sarana dan prasarana. Akses pemanfaatan teknologi didunia pendidikan sebenarnya sangat banyak dengan adanya aplikasi-aplikasi buah dari inovasi anak bangsa. Peranan teknologi dalam dunia pendidikan semakin kesini semakin terlihat dan dibutuhkan. Untuk mencapai pembelajaran yang efektif dan efisien perlu adanya rancangan, analisis serta potensi yang memenuhi kriteria dalam kegiatan pembelajaran. Efektif dan efesien memiliki arti bahwa pendidikan diharapkan dapat berlangsung dengan meminimalisir pengeluaran biaya, waktu dan tenaga untuk mencapai tujuan pembelajaran. Hal tersebut dikarenakan teknologi pendidikan dapat memberikan peranan terhadap kemampuan belajar dengan berbagai media serta penyajian yang telah disusun sepraktis mungkin.

\section{METODE}

Metode penelitian yang digunakan peneliti adalah metode kualitatif. Teknik pengumpulan data yang digunakan adalah wawancara dan studi dokumen atau teks (document studies). Dimana pendekatan ini menggunakaan berbagai referensi seperti buku, jurnal, artikel, makalah, wawancara pada Guru dan sumber bacaan sebelumnya yang sejenis, dengan tujuan agar penelitian ini mendapatkan landasan teori mengenai apa yang akan diteliti. Metode kualitatif lebih menekankan pada pengamatan fenomena dan lebih meneliti ke substansi makna dari fenomena tersebut.

Analisis dan ketajaman penelitian kualitatif sangat berpengaruh pada kekuatan kata dan kalimat yang digunakan. Penelitian dengan metode kualitatif ini diambil tidak dalam bentuk angka, namun berupa penjabaran mengenai urgensi teknologi pendidikan dalam meningkatkan kualitas pembelajaran daring . Tahapan penelitian yang dilakukan yakni berupa persiapan, pelaksanaan, dan pengolahan data. Dalam pengumpulan data primer, penelitian ini menggunakan teknik studi kepustakaan (Library Research) dan wawancara (Ali dan Erihadiana, 2021).

\section{HASIL DAN PEMBAHASAN}

\section{Pengertian Teknologi Pendidikan}


Teknologi dalam Bahasa Yunani berasal dari kata "technologia" yang menurut Webster Dictionary memiliki arti sebagai suatu systematetic treatment atau penanganan terhadap sesuatu secara sistematis dan sesuai pada kaidahnya (Sudarsana et al., 2018). Teknologi juga dapat diartikan sebagai seni, ketrampilan, ilmu dan juga keahlian yang digunakan manusia untuk berkreatifitas. Dengan demikian, teknologi dapat diartikan sebagai suatu proses pengembangan terorganisir dan sistematis yang didapatkan melalui pengamatan, pengalaman dan studi.

Menurut Undang-Undang Nomor 20 Tahun 2003 tentang Pendidikan Nasional, pendidikan merupakan upaya sadar dan terencana untuk membentuk suasana belajar dan proses pembelajaran sehingga peserta didik dapat mengembangkan potensi yang dimiliki untuk membentuk kekuatan spiritual, kecerdasan, pengendalian diri, akhlak mulia, kepribadian dan keterampilan untuk diterapkan pada kehidupan sehari-hari.

Hal ini selaras dengan ungkapan dalam Kamus Besar Bahasa Indonesia (KBBI) teknologi pendidikan memiliki makna sebagai suatu sistem dalam dunia pendidikan yang berperan sebagai suatu teknologi yang merencanakan, menggunakan dan untuk menilai seluruh proses kegiatan belajar mengajar dengan tidak mengabaikan berbagai sumber teknis, sumber daya manusia (SDM), serta suatu interaksi yang terjadi diantara keduanya. Dalam hal ini diharapkan agar bentuk pendidikan menjadi lebih efektif (Padmini dan Tyagita, 2015).

Teknologi Pendidikan dapat diartikan sebagai suatu alat bantu guna meningkatkan serta memperbaiki proses pembelajaran yang dilakukan siswa sehingga tercapai tujuan pembelajaran sesuai dengan kurikulum yang berlaku. Teknologi pendidikan juga diartikan sebagai kajian maupun praktik untuk membantu proses belajar sebagai upaya peningkatan efektifitas kinerja dengan cara membuat, memanfaatkan, serta mengelola sumber teknologi yang dibutuhkan. Penggunaan kata teknologi pendidikan seringkali dikaitkan dengan kegiatan belajar mengajar. Jika kegiatan belajar mengajar meliputi proses sekaligus sistem yang digunakan dalam kegiatan pembelajaran, maka teknologi pendidikan meliputi sistem lain yang dibutuhkan dalam proses mengembangkan kemampuan pelaku teknologi atau manusia (AECT, 2004). 
Teknologi pendidikan merupakan sebuah sistem yang digunakan dalam pembelajaran untuk membentuk pelajaran yang lebih efektif (Lestari, 2018). Teknologi pendidikan digunakan sebagai suatu sistem yang dapat memecahkan masalah dengan melibatkan orang, prosedur, langkah serta analisis permasalahan yang berkaitan dengan kegiatan pembelajaran (Hasibuan, 2016). Teknologi pendidikan sering dikaitkan dengan pembelajaran. Apabila pembelajaran mencakup proses dan sistem belajar mengajar, teknologi pendidikan lebih mengarah pada sistem yang digunakan dalam proses pembelajaran. Ada banyak pendapat tentang teknologi pendidikan antara lain :

1. Secara umum teknologi pendidikan dan teknologi pengajaran dapat diartikan sebagai penerapan seseorang tentang teknologi, komunikasi di dalam pembelajaran atau pengajaran.

2. Teknologi pendidikan merupakan kajian dan praktik yang berperan untuk memfasilitasi belajar serta memperbaiki proses pembelajaran dengan ,memberikan inovasi serta memanfaatkan sumber-sumber teknologi sesuai dengan kebutuhan.

3. Pendidikan adalah proses pemanfaatan serta evaluasi mengenai teknik, sistemsistem, dan media yang digunakan untuk kegiatan pembelajaran.

4. Teknologi pendidikan adalah suatu proses pembelajaran yang meliputi manusia, prosedur, ide, perlatan yang digunakan untuk belajar dan organisasi untuk mengetahui masalah pada aspek pembelajaran, merancang dan penilaian.

5. Teknologi pendidikan dapat diartikan sebagai pendekatan yang digunakan dalam kegiatan pembelajaran dan tersusun secara sistematis.

6. Teknologi pendidikan adalah teknologi yang diciptakan oleh manusia kemudian dapat dimanfaatkan kapanpun dan dimanapun (Endangswitri, 2019)

\section{Peran Teknologi Bagi Pendidikan}

Pendidikan yang baik akan mampu melahirkan sumber daya yang berkualitas dan berdaya saing. Sehingga pendidikan menjadi salah satu bidang fokus untuk meningkatkan kualitas sumber dayanya. Teknologi pendidikan adalah disiplin ilmu yang menjadi jembatan dari berbagai permasalahan dalam pendidikan dan pembelajaran secara sistematis serta komprehensif. Dengan demikian secara tidak langsung, teknologi pendidikan memegang peran dalam meningkatkan 
kualitas sumber daya manusia baik secara perorangan maupun kelompok (Achyanadi, 2016).

Perkembangan masyarakat semakin menunjukkan bahwa teknologi pendidikan memegang kendali yang sangat besar dalam peningkatan mutu pendidikan disemua jenjang pendidikan. Secara makro, teknologi pendidikan digunakan dalam merancang konsep dan pelaksanaan pendidikan secara nasional. Akses pendidikan untuk semua tidak bisa didekati dengan cara tradisional. Kita membutuhkan teknologi untuk memungkinkan seluruh masyarakat dapat menikmati pembelajaran yang merupakan hak mereka sebagai warga negara.

Sedangkan secara mikro, teknologi pendidikan digunakan sebagai pencapaian kualitas pembelajaran. Kualitas pembelajaran indikatornya harus terukur. Agar dapat mencapai indikator-indikator tersebut dibutuhkan pendekatan teknologi dalam pengertian yang sebenarnya, tidak terbatas pada perangkat pembelajaran semata tetapi terintegrasi secara sistemik dan pemanfaatan sumber belajar yang bervariasi (Suhada, 2017).

Dapat dikatakan bahwa teknologi digunakan untuk mendukung keberhasilan pembelajaran berdasarkan pemahaman teknologi pendidikan di atas. Berikut adalah beberapa peran teknologi pendidikan dalam penyelenggaraan pendidikan yang berkualitas.

1. Menyediakan perangkat pembelajaran melalui proses perencanaan, pengembangan, penggunaan, pengelolaan dan evaluasi sumber belajar;

2. Mengintegrasikan berbagai disiplin ilmu dalam format yang terintegrasi untuk memecahkan masalah pembelajaran yang ada dan mempelajarinya secara cermat.

3. Pemanfaatan teknologi untuk efektivitas dan efisiensi kerja, baik produk maupun proses untuk memecahkan masalah pendidikan;

4. Memberikan solusi alternatif untuk masalah kinerja organisasi secara terstruktur menggunakan produktivitas dan desain pendidikan.

5. Dapat menciptakan ide baru dalam pendidikan dan pelatihan untuk mengatasi permasalahan yang ada (Habibah et al., 2020).

Selain itu, peran teknologi pendidikan dalam proses pembelajaran sangat penting terutama di masa pandemi seperti sekarang ini. Dengan adanya wabah 
covid-19, semua kegiatan termasuk kegiatan pendidikan dan pembelajaran, harus dilakukan di rumah. Dalam rangka memutus penyebaran virus covid-19, kegitan belajar mengajar yang awalnya dilakukan di dalam kelas sekarang dilakukan melalui forum virtual.

Oleh karena itu, teknologi sangat dibutuhkan dalam proses pembelajaran online. Berkaitan dengan hal tersebut, ditegasskan oleh Buselich M., Tawakku T. et al., Dalam (Latip, 2020) bahwasannya inti dari pembelajaran online adalah bagaimana cara memilih metode pengajaran yang benar dengan menggunakan teknologi yang dirancang untuk menyediakan materi belajar kepada siswa. Bahkan jika mereka tidak memiliki akses untuk pembelajaran tatap muka seperti biasanya. Dengan kata lain, teknologi berfungsi sebagai wahana untuk berinteraksi dan mengkomunikasikan informasi terkait pembelajaran saat melaksanakan pembelajaran online.

Seperti halnya perangkat lunak atau software, teknologi berperan besar dalam pembelajaran, terutama dalam kondisi wabah covid-19 seperti saat ini. Teknologi membuat pembelajaran jarak jauh menjadi mudah bagi guru dan siswa. Untuk memfasilitasi pelaksanaan pendidikan jarak jauh, disediakan berbagai jenis platform yang berbeda. Google Docs dapat digunakan untuk menyelenggarakan diskusi, memungkinkan guru untuk mengevaluasi peserta didik dengan mudah tanpa pertemuan tatap muka. Mengadakan kuis melalui website ataupun aplikasi, serta mengikuti tes menggunakan Google Form. Dengan mengakses website dan beberapa aplikasi seperti, edutafsi.com, wolframalpha.com, slideshows, inspigo dan lainnya dapat membantu siswa untuk mempelajari mata pelajaran yang tidak bisa dipelajari memalui pendidikan jarak jauh. Teknologi juga berfungsi untuk meningkatkan kreativitas guru dan siswa, serta pendidik dapat berinovasi dalam penyampaian materi ajar menggunakan berbagai situs media sosial seperti facebook, instagram dan youtube. Seperti guru dan siswa dapat menggunakan berbagai situs jejaring sosial untuk melakukan tugas yang diberikan. Dalam hal ini, teknologi dapat membantu dan mendukung keberhasilan pembelajaran online di masa pandemi saat ini.

Teknologi pendidikan memang memiliki peranan yang penting dalam meningktakan mutu serta kualitas pendidikan, namun sama pentingnya untuk 
melakukan pemerataan dalam pendidikan. Hal ini berdampak negatif bagi kehidupan masyarakat luas dan dapat menjadi masalah dalam dunia pendidikan jika tidak segera diatasi. Teknologi pendidikan dapat menjadi jawaban dari berbagai permasalahan yang timbul dalam pembelajaran, namun apakah teknologi dapat dimanfaatkan dengan baik atau tidak tergantung pada kesiapan sumber daya manusianya. Hal ini mempengaruhi hasil dari penggunaan teknologi pendidikan. Oleh karena itu, pelatihan dan peningkatan SDM diperlukan agar dapat membangun organisasi pendidikan yang berdaya saing tinggi.

\section{Kendala Teknologi Pendidikan Di Masa Pandemi Covid-19}

Keberadaan teknologi saat ini yang semakin canggih dapat meningkatkan produktivitas pendidikan, saat ini dunia tengah dihadapkan dengan adanya virus covid-19, dengan adanya teknologi ini dapat mempermudah laju tahap belajar dan dapat memaksimalkan pembelajaran dengan baik sehingga seorang guru dan siswa dapat mengembangkan kegiatan belajar mengajar dengan memperluas materimateri yang akan disampaikan oleh pendidik. Adanya wabah covid-19, dunia pendidikan membuat kebijakan baru dengan mengubah sistem belajar mengajar yang sebelumnya tatap muka menjadi pembelajaran online atau daring (dalam jaringan) (Hanifah Salsabila et al., 2020).

Perkembangan teknologi pendidikan sampai detik ini mmenyumbangkan banyak variasi pada kegiatan belajar mengajar. Diantara dampak-dampak teknologi pendidikan dimasa pembelajaran jarak jauh pada saat pandemi ini yaitu, pertama, adanya berbagai platform-platform pembelajaran baru. Dalam terciptanya platform-platform ini memudahkan para pendidik dan peserta didik menjalani proses pembelajaran dari rumah atau jarak jauh. Adanya paltform-paltform ini dapat memberikan pengetahuan dan pengalaman baru kepada guru dan peserta didik mengenai perkembangan teknologi saat ini. Hadirnya platform-platform ini menjadi jembatan guru dan peserta didik dalam melangsungkan belajar mengajar pada saat pandemi dan juga dapat memahami pembelajaran yang disampaikan kepada guru saat pembelajaran berlangsung. Kedua, perkembangan teknologi ini dapat memudahkan peserta didik dan pendidikan dalam mencari sumber belajar yang mereka butuhkan. Peserta didik dan pendidik juga dapat mengakses internet melalui teknologi yang digunakan. Namun, apabila peserta didik tidak 
menggunakan teknologi dengan baik maka kemungkinan terburuknya bagi peserta didik adalah dapat mengakses hal-hal yang dapat merusak moral mereka. Ketiga, memberi kemudahan kepada pendidik untuk menjelaskan materi yang akan disampaikan kepada peserta didik. Teknologi pendidikan memiliki peran yang sangat penting dimasa pandemi ini karena pembelajaran akan lebih luas dilakukan tanpa harus pembelajaran tatap muka (Habibah et al., 2020).

Dalam pembelajaran daring banyak sekali platfrom-paltfrom yang digunakan untuk pembelajaran di kelas diantaranya adalah menggunakan zoom meeting, google meet, google clasroom, elearning, youtube, dll. Penggunaan media internet di masa pembelajaran saat ini mempunyai kendala yang cukup besar, jaringan internet yang kurang baik dan kesalahan teknis seperti server error ini juga akan menjadikan tidak efektif dalam pembelajaran. Putri Mahmudah guru PAI SD Negeri Bojong mengatakan bahwa kendala pembelajaran online ini adalah tingkat pemahaman murid berbeda-beda juga ditambah dengan sinyal yang kurang mendukung, waktu dalam penjelasan materi juga terbatas sehingga belum selesai menjelaskan materi waktu sudah habis dan apabila pembelajaran siang hari terkadang murid-murid sudah tidak fokus dalam pembelajaran misalnya sudah mengantuk. Beberapa kendala-kendala pada saat pembelajaran online diantaranya: 1. Orang tua siswa yang kurang tau tentang teknologi.

Kebanyakan orang tua diperdesaan tidak mengetahui tentang teknologi, karena kebanyakan orang di desa bekerja sebagai petani, kuli bangunan, peternak, dan lain-lain dan jarang sekali yang memiliki handphone berbeda dengan orang kota.

2. Jaringan internet yang kurang bagus.

Jaringan internet juga menjadi kendala bagi kebanyakan peserta didik dan orang tua yang melakukan pembelajaran secara daring, khususnya di daerah pedalaman ini sangatlah susah dalam mencari sinyal. Kendala lain adalah kouta internet, maka peserta didik dan orang tua harus mengeluarkan uang untuk membeli kuota internet dan dimasa pandemi ini ekonomi orang tua juga kurang baik dan orang tua juga kesusahan dalam membeli kuota internet juga tidak semua rumah memiliki wifi.

3. Para siswa sulit dalam memahami materi pembelajaran. 
Pada saat pembelajaran online ini siswa mengalami kesulitan dalam memahami pembelajaran yang disampaikan kepada guru akibat akses internet mengalami gangguan sinyal, bahkan saat tatap muka pun siswa masih belum paham apa yang disampaikan oleh guru.

4. Siswa merasa rasa malas dan sulit berkonsentrasi

Dengan adanya pembelajaran secara daring ini membuat peserta didik merasa malas dan juga akan sulit untuk berkonsentrasi. Peserta didik juga merasa pusing dengan tugas-tugas yang diberikan, dan saat membelajaran daring ini siswa lebih banyak dalam menggunakan HP, maka siswa akan lebih mudah dalam bermain game, membuka instagram, youtube, twetter dan media sosial lainnya. Dengan ini siswa akan merasa malas dan kurangnya konsentrasi pada saat pembelajaran berlangsung dan saat diberikan tugas (Mutiara, 2021) .

Adanya peningkatan kualitas dan kuantitas dari teknologi pendidikan yang semakin berkembang memberi dampak yang begitui pesat dalam kehidupan seharihari, salah satunya dibidang teknologi. Penigkatan ini tentunya akan membawa dampak positif dan juga dampak negatif. Adanya teknologi ini dapat memudahkan seseorang dalam berkomunikasi dengan baik dan pada saat pandemi ini kegiatan pembelajaran juga dapat dilakukan dengan jarak jauh. Peningkatan teknologi ini juga dapat merubah tatanan sosial dimasyarakat seperti tidak bisa berinteraksi dengan keadaan sekitar. Didunia pendidikan keterampilan yang didapatkan peserta didik adalah komunikasi dan berbicara, saat pandemi ini pembelajaran menggunakan internet dapat mengurangi kreatifitas peserta didik dalam berbicara dan berkomunikasi sebab mereka hanya melakukan interaksi dengan mesin.

Pembelajaran secara online dapat diartikan sebagai sebuah interaksi antara peserta didik dan pendidik yang dilakukan melalui media elektronik seperti handphone, komputer, dan lain sebagainya. Pembelajaran secara online dapat dikategorikan menjadi dua, yaitu:

\section{Synchronous Learning}

Pembelajaran daring jenis ini, menyarankan seorang pendidik melakukan pembelajaran melalui penayangan vidio langsung dan suara dalam satu waktu. Pendidik bisa berinteraksi secara langsung dengan peserta didik melalui beberapa pertanyaan yang diajukan. 


\section{Asynehronous (Collaborative) Learning.}

Peserta didik dapat mengikuti pembelajaran secara daring dengan ketentuan waktu yang mereka sepakati sendiri sehingga pendidik memiliki waktu yang lebih fleksibel untuk menjawab pertanyaan (Sudarsana et al., 2018).

Dalam perkembangan teknologi ini peserta didik harus bisa memanfaatkan teknologi dengan baik untuk menambah pengalaman, pengetahuan dan juga keterampilan, maka mereka akan mendapatkan prestasi yang baik. Sebaliknya, apabila peserta didik tidak menggunakan teknologi dengan baik maka mereka tidak akan mendapatkan prestasi bahkan akan membawa mereka kepada hal-hal negatif. Dalam teknologi pendidikan dampak positifnya yaitu dapat dilakukan pembelajaran jarak jauh, waktu penyelenggaraan pembelajaran fleksibel, peserta didik yang memiliki keterbatasan tempat tinggal sehingga membutuhkan biaya besar, waktu yang lama, dengan ini peserta didik dapat melakukan pembelajaran seperti halnya dengan tatap muka (Lestari, 2018).

Dimasa pandemi ini pemerintah memberlakukan kebijakan untuk menjaga jarak yang kemudian pelaksanaan pembelajaran dilakukan dari rumah dengan memanfaatkan teknologi pendidikan dan memakai platform-platform baru, hal ini membuat peserta didik dan orang tua menjadi kaget dengan kebijakan tersebut. Dengan pembelajaran secara daring seorang guru harus mengubah sistem pembelajaran dan proses belajar yang efektif, sebagai peserta didik juga merasa terbata-bata karena banyaknya tugas selama pembelajaran daring. Dengan ini sebagai orang tua yang mendampingi belajar siswa juga kurang paham mengenai teknologi digunakan bahkan tidak semua orang tua paham materi yang diajarkan oleh guru khususnya orang pedesaan dan hidupnya kurang mampu.

Abdul Hakim mengatakan ada beberapa kendala saat mengajar daring diantaranya: Pertama, peserta didik yang belum siap untuk belajar secara daring, sebenarnya bukan hanya peserta didik yang belum siap, saya sendiri pun dari hati paling dalam belum siap tapi keadaan yang memaksa harus siap dan tetap siap. Kedua, dampak dari ketidaksiapan peseta didik dalam menghadapi pembelajaran daring seperti beberapa peserta didik yang belum paham cara masuk Google Classroom. Ketiga, tidak semua peserta didik memiliki komputer/laptop. bahkan 
ada yang tidak memiliki gawai, bayangkan bagaimana mengikuti pembelajaran daring jika gawai saja tidak punya. Keempat, dalam proses pembelajaran daring melalui Google Classroom maupun WhatsApp ada sebagian peserta didik yang tidak dapat mengikutinya dikarenakan terkendala masalah kuota/data internet. Kelima, dalam menyampaikan materi pembelajaran dipilih beberapa kompetensi dasar yang esensial, yang menjadi tantangan agar peserta didik paham terhadap materi dari salah satu KD ialah satu materi bisa disampaikan dua bahkan tiga pertemuan. Dalam hal pengumpulan tugas peserta didik terkadang tidak semuanya mengumpulkan tepat pada waktunya, sebagai solusinya ada jangka waktu pengumpulan tugas satu minggu atau dua minggu tergantung materi yang diajarkan diajarkan olah guru mata pelajarannya (Oktavia, 2021).

Ada beberapa kendala umum yang selalu dihadapi pendidik dan peserta didik dalam pelaksanaan belajar mengajar daring, di antaranya:

1. Dalam sistem pembelajaran jarak jauh pada saat pandemi covid-19 ialah kurangnya bimbingan dari guru dan hanya didampingi dengan orang tua maka komunikasi peserta didik dengan guru sangatlah kurang.

2. Dalam mata pelajaran pendidikan jasmani ini seorang guru tidak mampu memanfaatkan teknologi pendidikan karena dalam pelajaran pendidikan jasmani membutuhkan praktek dan tidak semua peserta didik memiliki handphone.

3. Sebagai seorang guru di sekolah yang pendidikannya tidak linier mendadak menjadi guru penjas, ini akan menjadi kendala karena sebagian dari mereka kurang memahami pendidikan jasmani olahraga dan kesehatan bahkan mata pelajaran pendidikan jasmani olahraga dan kesehatan dianggap pelajaran yang tidak penting.

4. Dalam pembelajaran daring ini kendalanya adalah akses internet yang kurang baik di wilayah-wilayah pedalaman dan pedesaan yang tidak semua bisa menerima sinyal dengan baik.

5. Sebagai guru penjas juga kebingungan dalam memilih platform karena dalam pembelajaran penjas ini banyak sekali praktek yang dilakukan. 
Apabila guru mata pelajaran pendidiikan jasmani olahraga dan kesehatan tidak menindaklanjuti kendala tersebut maka prestasi akademik peserta didik akan menurun dan menimbulkan masalah kebugaran pada peserta didik (Oktavia, 2021).

Adanya kendala tersebut menjadi catatan yang sangat penting di dunia pendidikan karena sebagai seorang guru harus siap dalam mengajar pembelajaran secara daring. Pembelajaran online ini hanya sebagai konsep, sebagai perangkat teknis untuk dapat melangsungkan pembelajaran. Pembelajaran daring ini bukan metode untuk mengubah pembelajaran tatap muka dengan teknologi bukan pula untuk membebani peserta didik dengan tugas-tugas yang menumpuk setiap hari. Pembelajaran secara online bertujuan mendorong peserta didik agar menjadi kreatif yang dapat mengakses banyak sumber pengetahuan, menghasilkan karya, mengasah wawasan dan juga dapa meningkatkan prestasi siswa. Dengan begitu siswa tidak bergantung kepada guru untuk mendapatkan suatu pengetahuan, namun siswa dilatih untuk mendapatkan informasi atau pengetahuan melalui berbagai media pembelajaran. (Rais Tsaqif Yahya Al-Hakim, 2021).

Dari kendala-kendala pembelajaran yang terjadi pada saat covid-19 tentunya memiliki solusi-solusi untuk mengatasi tersebut diantaranya:

1. Membuat media pembelajaran sistem daring.

Dalam pembelajaran daring ini media yang digunakan tidak hanya dengan zoom meeting, google meet karena tidak semua orang tua murid memiliki handphone, jadi seorang guru harus membuat media pembelajaran.

2. Komunikasi dengan wali murid

Dalam adanya komunikasi pendidik dengan orang tua maka sangatlah penting karena pembelajaran daring ini orang tualah yang bisa memantau belajar siswa di rumah.

3. Membuat ringkasan pembelajaran

Seorang guru harus memiliki kreatifitas dalam mengajar di kelas, seorang guru perlu memiliki ringkasan materi agar para siswa paham apa yang disampaikan kepada guru.

4. Memberikan tugas-tugas yang mendorong siswa untuk aktif 
Dalam pembelajaran daring ini kebanyakan siswa mengeluh tentang banyaknya tugas yang diberikan dan tidak semua siswa paham dengan pelajaran yang disampaikan dari guru maka guru harus memberikan tugas sesuai porsi siswa dengan tujuan mendorong siswa untuk tetap aktif (Oktavia, 2021).

Solusi-solusi ini mampu mengurangi kendala-kendala pada saat pembelajaran daring berlangsung. Sebagai seorang guru harus memiliki solusi dari setiap kendala pembelajaran dan guru harus memiliki kreatifitas dalam pembelajaran di kelas dengan menciptakan suasana kelas yang menyenangkan. Pada saat pembelajaran daring ini juga guru dapat menyiapkan metode pembelajaran yang menarik agar siswa tidak bosan dalam mengikuti pembelajaran seperti membuat power point, membuat vidio pembelajaran sesuai materi dan lainlain. Ketika peserta didik terkendala sinyal, guru harus bisa mencari solusi agar semua peserta didik dapat menerima semua materi dengan sama. Solusi yang bisa dilakukan guru untuk peserta didik yang terkendala sinya yaitu, guru bisa memberikan tugas pada peserta didik yang kemudian dikirim memalui whatsaap. Tugas yang guru berikan bisa berupa pembuatan vidio ataupun menulis tulisan sesuai kreativitas peserta didik masing-masing.

Untuk mengatasi peserta didik yang kurang konsentrasi pada saat pemebelajaran daring, guru dapat memberikan ice breaking kepada semua peserta didik untuk menumbuhkan semangat peserta didik agar semua materi yang telah guru sampaikan dapat diterima dengan baik bagi peserta didik. Peserta didik yang kurang aktif dalam pembelajaran ataupun dalam pengumpulan tugas guru bisa ditunjuk untuk menjelaskan materi yang telah disampikan. Untuk peserta didik yang tidak aktif dalam mengumpulkan tugas, guru bisa mengatasi dengan menanyakan kepada orang tuanya. Sehingga apa yang menjadi masalah bisa jelas dengan menanyakan kepada orang tua peserta didik.

\section{SIMPULAN}

Berdasarkan hasil penelitian ini membahas tentang urgensi teknologi pendidikan dalam peningkatan kualitas pembelajaran daring dapat disimpulkan bahwa: 
1. Pembelajaran berbasis teknologi adalah alat bantu yang digunakan untuk pembelajaran agar pembelajaran menjadi efektif dalam pembelajaran darıng.

2. Peran teknologi pada saat pandemi ini sangatlah penting dalam pelaksanaan pembelajaran teknologi pendidikan, yaitu digunakan sebagai alat untuk berinteraksi antara pendidik dan peserta didik dalam pelaksanaan pembelajaran online.

3. Dalam proses pembelajaran secara darıng ada beberapa kendala diantaranya adalah tidak semua murid memiliki handphone juga ekonomi orang tua tidak memadai, susahnya sinyal, kuota internet dan peserta didik merasa bosan karena hanya berinteraksi dengan teknologi dan juga peserta didik dapat terus menggunakan handphone, dengan ini peserta didik hanya bermain game, bermain media sosial, dan lain-lain.

\section{DAFTAR RUJUKAN}

Achyanadi, S. (2016). Peran Teknologi Pendidikan dalam Meningkatkan Kualitas SDM. Jurnal Teknologi Pendidikan, 5(1).

Ali, A., dan Erihadiana, E. (2021). Peningkatan Kinerja Teknologi Pendidikan dan Penerapannya pada Pembelajaran Pendidikan Agama Islam . Jurnal Dirosah Islamiyah, 3(3), 332-341. https://doi.org/10.47467/jdi.v4i1.445

Habibah, R., Salsabila, U. H., Lestari, W. M., Andaresta, O., dan Yulianingsih, D. (2020). Pemanfaatan Teknologi Media Pembelajaran di Masa Pandemi Covid19. Trapsila: Jurnal Pendidikan Dasar, 2(02), 1. https://doi.org/10.30742/tpd.v2i2.1070

Hanifah Salsabila, U., Irna Sari, L., Haibati Lathif, K., Puji Lestari, A., dan Ayuning, A. (2020). Peran Teknologi Dalam Pembelajaran Di Masa Pandemi Covid-19. Al-Mutharahah: Jurnal Penelitian Dan Kajian Sosial Keagamaan, 17(2), 188-198. https://doi.org/10.46781/al-mutharahah.v17i2.138

Hasibuan, N. (2016). Pengembangan Pendidikan Islam Dengan Implikasi Teknologi Pendidikan. FITRAH:Jurnal Kajian Ilmu-Ilmu Keislaman, 1(2), 189. https://doi.org/10.24952/fitrah.v1i2.313

Lestari, S. (2018). Peran Teknologi dalam Pendidikan di Era Globalisasi. Edureligia; Jurnal Pendidikan Agama Islam, 2(2), 94-100. https://doi.org/10.33650/edureligia.v2i2.459 
Merliana, N. P. E. (2019). Peranan Teknologi Dalam Peningkatan Mutu Pendidikan Pembelajaran Bahasa Di SMAN 1 Katingan Hulu Kabupaten Katingan. Jurnal Penjaminan Mutu, 5(2), 214. https://doi.org/10.25078/jpm.v5i2.895

Mutiara, O. (2021). Tantangan Pendidikan Di Masa Pandemi Semua Orang Harus Menjadi Guru. Jurnal Pendidikan Dan Konseling, 3(3).

Oktavia, S. A. (2021). Pandemic Effect (Hikmah Dan Kisah Para Perjuangan Pendidikan Di Masa Pandemi).

Padmini, K. H., dan Tyagita, B. P. A. (2015). Teknologi Pendidikan Sebagai Pembelajaran Kompetitif Untuk Meningkatkan Prestasi Siswa: Studi Kasus Di Salah Satu SMA Di Salatiga. Prosiding Seminar Nasional Pendidikan, November, 60. https://media.neliti.com/media/publications/171192-IDteknologi-pendidikan-sebagai-pembelajara.pdf

Rais Tsaqif Yahya Al-Hakim. (2021). Pembelajaran Online Di Tengah Pandemi Covid_19,Tantangan Yang Mendewasakan.

Sudarsana, i ketut, Fewi, ni luh putu seri setia, Sukarmiasih, ni putu, Resna, i ketut, Arini, ida ayu made putri, Restiti, ni wayan, Suryawan, i wayan, dan Limbong, T. (2018). Paradigma Pendidikan Bermutu Berbasis Teknologi Pendidikan. In Perpustakaan Nasional Republik Indonesia Katalog Dalam Terbitan (KDT) (Issue 1).

Suhada, S. (2017). Peranan Teknologi Pendidikan dalam Peningkatan Mutu Pendidikan. Hikmah: Journal of Islamic Studies, 13(2), 49. https://doi.org/10.47466/hikmah.v13i2.152 